\title{
Sosialisasi Islam Di Jawa Abad Ke 15-17: Radikal Atau Persuasif? (Telaah atas Historiografi Lokal dan Asimilasi Tinggalan Arkeologis)
}

\section{Irna Saptaningrum}

Keywords: distribution, religion, diffusion, assimilation, culture, history

\section{How to Cite:}

Saptaningrum, I. (2004). Sosialisasi Islam Di Jawa Abad Ke 15-17: Radikal Atau Persuasif? (Telaah atas Historiografi Lokal dan Asimilasi Tinggalan Arkeologis). Berkala Arkeologi, 24(1), 72-86. https://doi.org/10.30883/jba.v24i1.896

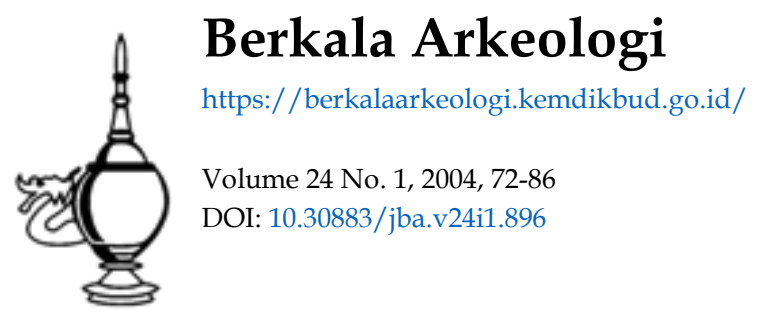

\section{c) (7)(2) (2)}

This work is licensed under a Creative Commons Attribution-NonCommercial-ShareAlike $\underline{4.0 \text { International License. }}$ 


\title{
SOSIALISASI ISLAM DI JAWA ABAD KE 15-17: \\ RADIKAL ATAU PERSUASIF ? \\ (Telaah atas Historiografi Lokal dan Asimilasi Tinggalan Arkeologis)
}

\author{
Irna Saptaningrum
}

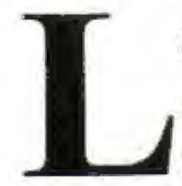

\section{atar Belakang}

Awal kedatangan Islam dan proses sosialisasinya di wilayah Nusantara merupakan satu perbincangan yang senantiasa mengundang polemik di antara para pakar studi ke-Islaman. Berbagai perbedaan pendapat berkisar pada periodisasi dan asal-muasal kedatangannya yang tidak mudah untuk dipastikan. Terlepas dari berbagai polemik yang ada, pengaruh Islam masuk diawali dari pesisir selat Malaka yang menjadi jalur lalu-lintas perdagangan internasional yang cukup ramai pada abad ke-7 dan ke-8 M. Meningkatnya arus perdagangan terutama diakibatkan dengan adanya persaingan dagang diantara tiga dinasti besar pada saat itu, yaitu Dinasti banu Umayyah di Asia Barat, Sriwijaya di Asia Tenggara dan dinasti T'ang dari Asia timur (Tjandrasasmita, 1976; Iqbal, 1995). Jadi arus perdagangan terbentang dari jazirah Arab, Persia, India (Gujarat), Indonesia (daerah Sriwijaya) dan Cina. Adanya kontak dagang inilah agama Islam mulai dikenal dan secara berangsur-angsur mulai berkembang pada masyarakat luas hingga tumbuh menjadi suatu kerajaan Islam pada abad ke-13, yaitu kerajaan Samudra Pasai.

Eksistensi kerajaan Samudra Pasai dibuktikan dengan adanya nisan kubur Sultan Malik As-Salih, wafat pada tahun $696 \mathrm{H}$ atau $1297 \mathrm{M}$, yang ditemukan di Gampong Samudra, $15 \mathrm{Km}$ dari Lhokseumawe; serta didukung pula dengan bukti berita asing, Hikayat Raja-raja Pasai dan Sejarah Melayu. Kerajaan yang bercorak Islam ini muncul bersamaan dengan mulai melemahnya pengaruh Kerajaan Sriwijaya, sebagai akibat ekspansi politik Singasari- Majapahit, juga ekspansi Cina pada masa Kubilai Khan di abad ke-13 dan masa Dinasti Ming pada abad ke-14-15 ke daerah Asia Tenggara (Tjandrasasmita, 1984). Selanjutnya, sekitar abad ke-16, sebagaimana dikutip dari berita Tome Pires, bahwa daerah-daerah pesisir Sumatera utara dan timur Selat Malaka, yaitu dari Aceh hingga Palembang, sudah banyak terdapat masyarakat dan kerajaan-kerajaan Islam.

Pengaruh Islam masuk ke Jawa, terutama di pesisir utara Jawa, mulai abad ke-11 dengan adanya bukti makam Fatimah binti Maimun bin Hibatallah, yang wafat pada tahun $475 \mathrm{H}$ atau $1082 \mathrm{M}$. Makam ini terletak di Leran, Gresik. Pada saat itu di Jawa masih berdiri kerajaan Majapahit yang cukup berpengaruh. Namun kondisi kejayaan 
Majapahit berangsur-angsur mulai berkurang diakibatkan oleh banyaknya konflik yang terjadi di antara keluarga raja-raja Majapahit sendiri. Baru pada abad ke-15, di daerah pesisir Jawa berdiri kerajaan Islam yang pertama, yaitu di Demak, dan sebagai penguasanya adalah Raden Patah (Tjandrasasmita, 1976, 1984). Dari Demak kekuasaan Islam disebarkan ke Cirebon dan Banten kemudian Sunda Kelapa di bawah Sunan Gunung Jati dan Fatahillah sehingga timbul kerajaan Cirebon (1475), Banten (1552), Jayakarta (1526). Sementara itu, kerajaan Pajajaran lambat laun mulai runtuh di bawah kekuasaan Banten (1579). Proses sosialisasi Islam dilakukan dengan caracara melalui saluran perdagangan, perkawinan, politik, tasawuf, pendidikan pesantren, serta kesenian (Tjandrasasmita, 1976, 1984). Namun kemudian yang menjadi permasalahan adalah bagaimanakah sosialisasi itu dilakukan ? Apakah sosialisasi tersebut dilakukan secara damai (bersifat persuasif) ataukah dengan menggunakan cara-cara yang radikal semacam peperangan?

Berkaitan dengan pertanyaan diatas, Suwedi Montana pernah menuangkan gagasan ke dalam kertas kerjanya yang pernah dimuat dalam buletin Forum Arkeologi (1996), yang menyoal tentang adanya perbedaan dalam cara penyebaran agama Islam di Jawa pada abad ke 15-17 dengan mendasarkan pada Kajian atas data historiografi lokal dan asimilasi tinggalan Arkeologi. Sebagai hasil akhir tulisannya, Montana (1996) memberikan simpulan bahwa terdapat perbedaan cara dalam penyebaran agama Islam di Jawa pada abad ke-15 - ke-17. Dari sumber historiografi lokal (Babad Banten dan Babad Pasir) dinyatakan bahwa Islam disebarkan atau disosialisasikan dengan benturan fisik (perang ?) jadi bersifat radikal. Sementara itu, tinggalan arkeologis yang ada merefleksikan adanya sikap yang cenderung persuasif, dengan terjadinya asimilasi dari dua aliran agama yang berbeda baik konsep maupun ritualnya. Dalam hal ini dicontohkan antara lain, adanya penggambaran mozaik kura-kura pada dinding mihrab Masjid Agung Demak, gapura candi paduraksa yang berada di dalam masjid Aqsa di Kudus.

Dengan mengadopsi cara pandang arkeologi pasca-prosesual (Post-modernisme), tulisan ini bermaksud untuk menafsirkan kembali data yang sama dengan mencari pemahaman atas gagasan atau ide dibalik yang tersurat dan kemudian dikorelasikan dengan tinggalan arkeologi yang ada. Sesuai dengan paham pasca-prosesual, maka sebagai hasil simpulan akhir bukanlah merupakan sesuatu yang 'hitam' atau 'putih', tapi lebih merupakan sesuatu perbedaan cara pandang yang menyebabkan sesuatu itu dipahami "sebagai hitam" dan "sebagai putih". Oleh karenanya, masih terus terbuka peluang untuk diinterpretasikan kembali secara terus menerus. 


\section{erangka Pikir}

Kerangka pikir dibangun dengan mengadopsi pandangan dari aliran arkeologi pasca-prosesual. Pandangan arkeologi pasca-prosesual yang dipengaruhi kerangka pikir post-modernism yang bersifat kritis dan dekonstruktif, berpendapat jika pengetahuan pada dasarnya adalah hasil sejarah atau tradisi, tidak ada yang obyektif dan merupakan sesuatu yang bias meskipun diperoleh dari pengujian 'ilmiah' sekalipun. Alasannya, adanya unsur gagasan subyektifitas si peneliti yang termuat dalam perangkat pengujiannya (berupa teori, dalil atau model) yang digunakan. Menurut pandangan aliran ini, budaya dipandang sebagai sesuatu yang refleksif, dengan maksud masyarakat tidak menjalankan budayanya secara pasif tapi secara aktif memberi 'arti' baru terhadap dunianya. Budaya bendawi sebagai bagian dari budaya, dijadikan sebagai sarana untuk menciptakan 'makna' dan tatanan dalam masyarakat tersebut, selain sekedar sebagai 'cerminan' gagasan atau organisasi sosial masyarakatnya. Oleh karena itu, 'makna' budaya bendawi setiap masyarakat akan selalu berubah dalam setiap tahap sejarah manusia. Konsekuensinya, teori, dalil atau model tidak lagi dipercaya mampu untuk menjelaskan dan mengungkapkan pengetahuan yang benar dengan alasan bahwa pengetahuan yang benar adalah sesuatu yang relatif dan subyektif (Hodder, 1991 a; 1991b; Thomas, 1989; Bahn dan Renfrew, 1991; dalam Tanudirjo, 1995).

Hodder salah seorang tokoh dari paham arkeologi post-modernisme sebagaimana dikutip oleh Tanudirjo (1994; 1995) mengatakan, perlunya memahami 'makna' (meaning) suatu aspek budaya dalam konteks budaya dan sejarahnya sendiri, pemahaman dilakukan secara internal atau emik. Menurut Hodder, tinggalan arkeologis dapat berbicara jika konteksnya mampu didapatkan, sehingga 'makna' budaya bendawi dapat dijelaskan. Untuk dapat memahami dan menjelaskan konteks budaya bendawi masa lampau, seharusnya dilakukan dengan pendekatan empatetik (emphatetic approach). Dalam pendekatan ini peneliti menempatkan diri sebagai bagian dari budaya yang ditelitinya. Dengan begitu "makna" suatu fenomena budaya mampu ditafsirkan dan dipahami sesuai dengan konteks aslinya yang spesifik. Bersamaan dengan itu, penjelasan yang diberikan hendaknya bersifat kritis dan dalam cakupan kerangka pikir yang lebih luas (generalisasi/teori) (Melas, 1991; Tanudirjo, 1994; 1995).

Semakin jelas bahwa kerja interpreter menjadi suatu kerja dalam arkeologi (arkeologi interpretif). Seorang interpreter harus bertanggung jawab terhadap tindakannya maupun hasil penafsirannya. Karenanya, hasil interpretasinya merupakan kerja masa kini yang diungkapkan menjadi suatu pengetahuan, narasi, laporan dan lain-lain, sebagai bentuk pemahaman tentang masa lampau dari sisa-sisa tinggalannya yang masih ada. Bentukannya menjadi suatu konstruk yang tidak kalah nyata, bisa dipercaya dan otentik. Praktek-praktek sosial semacam ini (arkeologi termasuk di 
dalamnya), ada kaitannya dengan 'pemaknaan', yaitu bagaimana suatu benda menjadi bermakna. Oleh karena itu, saat bekerja, berbuat, bertindak membuat semuanya bersifat interpretatif. Praktek interpretatif merupakan proses yang berkelanjutan, sehingga tidak ada hasil akhir dan pasti, karenanya kesimpulannya juga relatif sebagaimana yang dipikirkan sebelumnya. Dalam praktek sosial, interpretasi yang dilakukan lebih bertujuan untuk memahami mengapa itu terjadi, atau membuat 'sesuatu' yang tidak pasti dan tidak meyakinkan menjadi bermakna, sedangkan penjelasan sebab-akibat tidak begitu diperhatikan. Penafsiran bersifat multivokal, yaitu bahwa penafsiran yang berbeda terhadap sesuatu obyek yang sama merupakan hal yang biasa. Oleh karena itu, dapat dipahami jika dari data arkeologi yang sama terdapat beragam penafsiran, dan letak perbedaannya tergantung pada diri si interpreter akan tujuan, kebutuhan dan niatannya untuk melakukan penafsiran. Jadi dapat dikatakan di sini, bahwa interpretasi atau penafsiran adalah bentuk perhatian yang kreatif (menghasilkan sesuatu) dan kritis (tidak semena-mena) dan merupakan tanggapan terhadap minat, kebutuhan dan niat dari pihak-pihak yang berbeda, yaitu orang atau kelompok orang atau komunitas yang memiliki minat terhadap tinggalan masa lalu dan ingin mengungkapkannya.

Kerangka pikir seperti ini kemudian yang memicu pengaplikasian pendekatan hermeneutika oleh para pendukung arkeologi pasca-prosesual (Hodder, 1991c; Shank, 1992 dalam Tanudirjo, 1994; 1995). Pendekatan hermeneutika dianggap paling tepat untuk memahami masa lampau karena di dalamnya mencerminkan pola pikir pascamordernisme. Refleksi yang terkandung dalam pendekatan hermeneutika seperti peran individu, pemahaman dalam konteks luas, pendekatan empatetik, dan tidak bergantung teori dan dalil, dapat terwadahi. Dengan pendekatan hermeneutika yang berakar dari tata cara penerjemahan suatu teks, maka di sini data arkeologi diperlakukan layaknya suatu 'teks' atau catatan sejarah yang harus diterjemahkan dan seorang peneliti bertindak sebagai penerjemahnya. Saat proses 'penerjemahan' berlangsung terjadi suatu 'dialektika' antara bagian dan keseluruhan (part-whole dialectica) untuk mendapatkan pengertian dan pemahaman yang lebih benar. Dialektika yang terjadi antara penerjemah dengan yang diterjemahkan, antara pandangan masa kini (dalam benak peneliti) dengan pandangan masa lampau (latar budaya yang diteliti), antara bagian (budaya bendawi atau kasus) dengan keseluruhan (seluruh sistem budaya atau generalisasi) bukan suatu interpretasi yang statis namun interpretasi yang terus berlangsung dan berkembang (Hodder, 1991 c dalam Tanudirjo, 1994).

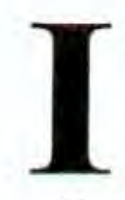

\section{nterpretasi awal.}

Montana berasumsi adanya perbedaan cara sosialisasi Islam dengan mendasarkan adanya pendapat yang menyebutkan bahwa penyebaran agama Islam di Jawa disebarkan dengan menempuh dua cara, yaitu : 
1. Cara Perorangan, cara ini cenderung dilakukan dengan damai tidak disertai adanya kekerasan atau benturan-benturan fisik.

2. Cara politis, cara ini dilakukan dengan resmi, cenderung radikal sehingga tidak jarang disertai kekerasan.

Cara perseorangan, dikaitkan dengan keberadaan tinggalan arkeologi yang merefleksikan proses asimilasi dan cara politis dikorelasikan dengan sumber historigrafi lokal, yang memuat tentang sosialisasi Agama Islam yang dilakukan oleh pembesar kerajaan. Di bawah ini akan diuraikan tentang pokok bahasan yang ada dalam naskah kerja Montana sebagai interpretasi awal.

Lebih lanjut sebagai data kajian, dalam tulisannya Montana memaparkan dua buah sumber naskah historiografi lokal berupa Babad, yang mewakili tentang cara penyebaran Islam yang pernah dilakukan di Jawa, yaitu, Babad Banten (penyebaran agama Islam di Pakuan Pajajaran) dan Babad Pasir (penyebaran agama Islam di Pasir Luhur, sebuah kadipaten di wilayah Banyumas). Kedua Babad ini menyebutkan bahwa penyebaran agama Islam dilakukan dengan jalan perang. Hal ini ditegaskan dengan merujuk pendapat de Graaf (1985) bahwa kelompok muslim yang ekslusif di bandar-bandar pesisir utara Jawa, menyerang bandar Demak dan Kudus (Graaf, 1985: 28-29). Namun di sini masih terlihat keraguan pada kebenaran bukti yang diungkapkan oleh Graaf.

Babad Banten ini adalah naskah tulis tangan dalam huruf pegon, yang tidak diketahui siapa penulisnya. Naskah ditulis dalam bahasa Jawa yang disalin ulang oleh Mujur Pabuaran bin Tubagus Haji Adullah pada tahun $1206 \mathrm{H}$ (1790 M). Babad Banten berbentuk prosa atau gancaran, dan muatan tentang penyebaran agama Islam terdapat pada halaman 24-27. Hasil kutipan tersebut diterjemahkan dalam bahasa Indonesia, sbb:

24.

$$
1-12
$$
.. Yang (akan) menyerang

14. sudah siap, maka berkatalah Mahdum Judah: "Ya Maulana, Bismillah,

15. La haula wala quwata illabillahil a'laiyil adzim, inilah waktu

l. Perang sabil yang suci. Lalu Maulana Judah membaca doa agar

2. tercapai apa yang diharapkan. Maka semua yang ada di situ mengaminkan

3. Maulana Judah. Pada waktu itu para Ajar sudah separoh yang 
4. diislamkan. Lalu Panembahan dan semua temennya (pada)

5. pergi dari situ. Waktu pelaksanaan (penyerangan) adalah hari Ahad tanggal

6. satu bulan Muharam tahun Alip. Maka Maulana Judah sudah menyerukan

7. takbir di sepanjang jalan bahkan sudah tiba di Desa Parungkasihaji. Maka

8. Panebahan Ratu Surasowan (Sultan Banten, Maulana Hasamuddin) beristirahat dan semua

9. bala tentara (yang berjumlah) hampir lima numbang (?), (dan) yang bertugas sebagai mata-mata adalah domas (800 orang) bersenjata (yang didapat) dari

10. Angke sebanyak dua ratus senjata, dari Gerege (Cerbon) delapan ratus, itu senjata dari

11. Maulana Bagdad; senjata dari demak ada lima aksa,

12. putranya dan menantunya dan Prabu dan para ponggawa dan para Ajarbdan warga

13. dari Gerage. Maka Ki Jongjo berdatang sembah kepada Panembahan

14. "jika diizinkan hamba mohon diri lebih dulu (untuk) berangkat serta

26.

1. mohon bantuan teman lima ratus agar mengikuti dibelakang

2. hamba. Nanti waktu tengah malam hamba masuk ke sarang musuh dan paduka mengepung

3. dari luar, hamba yang berkeliling sambil mengamuk dari dalam".

4. Maka berkatalah Maulana Yusuf, "Mengapa kamu mempunyai maksud demikian?"

5. Ki Jongjo menyahut, "Daulat Tuanku dari pintu selatan

6. sebab saudara hamba yang menjaganya

7. sebagai mentua Prabu Seda, ia mentuanya

8. oleh Prabu Seda ia diangkat sebagai Sanghyang Anaq.

9. hanya saudara-saudara hamba yang lain yang tidak diangkat itu sakit hati oleh karena itu hamba

10. berkata (akan) lewat pintu selatan

11. saudara hamba memutuskan (supcrya) hamba lewat pintu selatan 

12. Tetapi kelak kalau Tuan menang
13. hamba mohon kemerdeklaan". Berkatalah Maulana
14. Yusuf, "Insya Allah Ta'ala, niatmu akan kesampaian". Maka ki Jong
15. jo melakukan perang campuh.

27. I. Kalahlah ponggawa Pakuan, separoh sudah tewas, separoh yang lain dan kafir Buda (itu)

2. masuk Islam, tetapi yang rajanya bernama Parabu Seda musna

3. dan Pucuk umum dan Parabu Aleng-aleng (?), dan yang lain-lain dari mereka itu

4. semua hartanya sudah dijarah dan bahkan sudah di

5. suruh membaca (kalimat) Syahadat. Maka setelah selesai mengislamkan, Panembahan

6. mundur dari Pakuan dan berangkat ke Gerage bersama dengan temantemannya

7. hendak mengunjungi ayahandanya. Tak terceritakan di jalan, sudah

8. tiba di Gerage, bahkan sudah mencium kaki (ayahandanya). Maka

9. berkatalah Susuhunan Mahdum Jati, : "Syukur Ki Mas membagi-bagikan gonimah (harta rampasan perang).

10. Ini terjadi jika orang-orang tinggal di batas negeri (milik) ki Mas Tua (Pangeran Pasarean di Cercon) menjadi

11. milik Ki Mas Tua, (dan) kalau orang-orang itu berdiam di batas negeri (milik) Ki Mas

12. Anom (maka barang gonimah itu) menjadi milik Ki Mas Anom, sampai (pada) akhirnya aku diberi batas, Karawang ke timur

13. (adalah) milik Ki Mas Tua (sedangkan Kerawang) ke barat menjadi milik Ki Mas Anom". Adapun

14. ponggawa Panembahan Ratu Surosowan bernama Kyahi

15. Mahapati dan Kyahi Utama, adiknya(?) dan Kiyahi Senapati.

Sementara itu, Babad Pasir ditulis dengan huruf Jawa dalam tembang Macapat. Cerita ini pernah terbit pada tahun 1891 di Probolinggo oleh Schutemakker; dan ditulis ulang oleh pembantu Knebbel pada tanggal 28 Maret 1894, dan pada tahun 1896 diberi 
komentar oleh Knebbel, Asisten Residen di Magetan. Secara garis besar Babad ini bercerita tentang Raden Kamandaka alias Raden Banyak Catra (putra Prabu Siliwangi dari Pajajaran), yang kelak akan menggantikan mertuanya sebagai Adipati Pasir Luhur. Keturunan Raden Kamandaka sudah memeluk agama Budo (Hindu atau Buda, secara tradisional agama sebelum Islam disebut agama 'Budo'). Beberapa pupuh yang bereerita tentang penyebaran Islam dapat diuraikan, sebagaimana dikutip dari Montana (1996) sbb.

Pupuh Sinom, halaman 131 (angka Jawa)

Adipati Banyak Belanak (itu)

adiknya menjadi patih

bernama Patih Wilakancana

berkedudukan di Pasir Luhur.

Ganti yang diceritakan

Sang Prabu di Majapahit

keratonnya sudah bedah (hancur)

(sebab) agama Budo sudah berganti (Islam)

Raden Patah (yang) menjadi Sultan Demak

Pupuh Asmaradana, halaman 13 I (angka Jawa)

Terkisah di negara demak (yaitu)

Kang Jeng sultan Demak,

Pada hari senin

Pagi itu (Sultan) duduk di balairung.

Lengkap dengan semua balatentara

Besar kecil penuh sesak

Adapun yang duduk di bagian depan,

Yang terhormat Patih berdua,

Ki Patih Edin namanya,

Dan Ki Patih Husen.

Dan ada lagi seorang Wali

yang bergelar Pangeran Makedum

Wali itu menghadap ke depan.

Bertitahlah Seri Baginda

Kepada kedua patihnya.

"Patih edin, Patih husen,

Beta mendengar kabar

Bahwa kerajaan di barat (yang) sekarang

Bernama Pasir Luhur,

Dewasa ini masih memeluk agama budo. 
Dan negara itu selama ini

hanya medang kori (?)

belum kita taklukkan.

Adapun sekarang maksud Beta

Patih berdua berangkatlah

ke negara Pasir Luhur

lalu kalian Islamkan.

Dan Jebeng Makedum Wali

Beta perintahkan untuk mengislamkan

Kalian berdua sebagai ketibnya

Andaikata (raja itu) menolak untuk masuk Islam

Iku sira sirnakna (kalian bunuhlah dia)".

Kedua Patih itu (sudah) paham,

Sembahnya: "Daulat Tuanku"

(Knebbel, 1900).

Dari kedua sumber naskah historiografi lokal ini kemudian dipertentangkan dengan data arkeologis yang merefleksikan suatu sikap yang lebih bersifat persuasif dalam penyebaran agama Islam, yaitu adanya proses asimilasi dalam tinggalan arkeologi yang ada. Istilah asimilasi diadopsi dari ilmu sosiologi untuk menjelaskan proses dua kelompok manusia atau lebih yang mempunyai perbedaan sikap, nilai dan adat menjadi satu kesamaan dalam respek. Konsekuensinya, dari proses asimilasi itu, kelompok-kelompok tersebut melibatkan persamaan sehingga menjadi anggota dari satu masyarakat dan budaya yang lebih besar. Ada kemungkinan terjadi pergeseran budaya oleh kelompok subordinat yang lebih kuat (Montana, 1996).

Wujud asimilasi tinggalan arkeologi di Jawa tengah, Jawa Timur dan Cirebon merefleksikan penyebaran yang dilakukan dengan persuasif. Beberapa tinggalan arkeologis tersebut adalah sbb:

1. Lukisan mozaik berupa kura-kura pada dinding mihrab Masjid Agung Demak serta ukiran wayang berbentuk kepala raksasa di bagian pintu utama masjid.

2. Adanya pintu gerbang berbentuk paduraksa di dalam masjid Aqsa Kudus yang terletak pada garis lurus menuju pengimaman.

3. Umpak tiang utama masjid berbentuk Yoni ditemukan di masjid Besar Kota Purworejo, dua buah masjid besar di Kecamatan Purwodadi, masing-masing di Desa Jenar dan Desa Rawong.

4. Sebuah Lingga yang berdiri di mihrab masjid kuno di desa Lugurejo, Kecamatan Butuh, Purworejo.

5. Pintu utama pada masjid kuno Sang Ciptarasa, Cirebon, dibentuk seperti pintu candi dengan relief berbagai flora. 
6. Sebuah Yoni utuh terletak di depan sebuah masjid di Desa Brebek, Kecamatan Brebek, Nganjuk.

7. Di belakang masjid kuno 'Al-Kahfi', di Desa Sumberadi, Kebumen, terdapat 2 buah yoni besar, 4 buah lingga, dan batu-batu pelipit candi.

8. Sebuah stupa yang terletak di depan sebuah masjid kuno di Desa Pesantren, Kecamatan Bagelen, Purworejo.

Lebih lanjut dijelaskan bahwa dari bukti tinggalan arkeologis yang ada merefleksikan tindakan yang persuasif dengan mengawinkan dua kultur yang berbeda baik secara konsep maupun ritualnya dalam proses asimilasi. Konsep pemikiran asimilasi ini lebih lanjut dikatakan, sebagai upaya untuk dapat mengambil hati masyarakat diusahakan agar agama yang masih menjadi pegangan hidup rakyat dijaga dan diperhatikan sehingga masyarakat tidak merasa ada arus islamisasi. Jalan yang ditempuh dengan melakukan penetrasi pasifik, yaitu dengan membiarkan yoni, lingga, gapura paduraksa yang kebetulan terletak di tempat yang akan dibangun masjid. Keberadaan bendabenda tersebut dikamuflase sedemikian rupa sehingga tidak bertentangan dengan ajaran Islam. Yoni dikamuflir menjadi umpak, gapura paduraksa dibiarkan tetap berdiri bahkan dibuat imbangannya dengan mendirikan menara dalam bentuk seperti candi, penggambaran mozaik kura-kura dimaknai tidak semata-mata dalam wujud fisknya namun merupakan manifestasi bentuk pertanggalan (candrasengkala). Kondisi ini menghilangkan keraguan yang masih ada di hati rakyat untuk memasuki masjid, dengan pemikiran bahwa di dalam masjid masih dijumpai 'sesembahan' mereka. Lambat laun setelah mereka mulai terbiasa dengan kondisi ini, akhirnya mereka menjadi pasrah, berserah diri kepada keimanan Islam. Penyebaran agama Islam dalam hal ini dipelopori oleh para mubaligh Islam yang lebih dikenal dengan sebutan "wali" (Salam, 1960: 23).

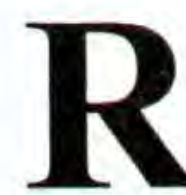

\section{eintepretasi Cara Sosialisasi Islam}

Dalam konteks temporal, ke-lampau-an identik juga dengan sejarah. Kata sejarah sendiri mengandung muatan pengertian yang ambivalen, serba-dua, yaitu kaburnya pengertian sejarah sebagai kejadian di masa lampau dan sejarah sebagaimana diceritakan (Walsh, 1956 dalam Abdullah, 1985: 2). Pengertian pertama merupakan aspek yang tidak tersentuh, di mana sejarah merupakan "sesuatu yang terjadi", dikatakan atau tidak, diceritakan atau tidak. Sedangkan pengertian kedua telah melekat di dalamnya upaya untuk menceritakan dan menerangkan apa yang terjadi, dalam hal ini seluruh kegiatan dan aktivitas manusia dan akibat yang ditimbulkannya sebagai daerah perhatian. Upaya penulisan sejarah juga dijumpai adanya pembauran antara "peristiwa sebagaimana-ia-terjadi-sesungguhnya" dengan "peristiwa sebagaimana-ia-dimengerti" (Abdullah, 1985: 3). 
Bicara tentang penulisan sejarah berkaitan erat dengan istilah historiografi. Pengertian historiografi menurut Webster's Third International Dictionary (1966), adalah penulisan sejarah terutama penulisan sejarah yang berdasar atas pengujian-pengujian yang kritis terhadap sumber-sumber khusus yang terseleksi dari bahan-bahan yang otentik dan sintesa dari hal-hal yang khusus itu menjadi semacam narasi. Namun historiografi dapat pula diartikan sebagai produk penulisan sejarah misalnya sastra sejarah atau historical literature (Montana, 1996: 12). Aspek narasi sebagaimana terdapat dalam kutipan di atas, memungkinkan munculnya unsur subyektivitas dalam penulisan sejarah, sehingga mengurangi kadar keotentikan suatu 'peristiwa'. Di Indonesia naskah historiografi dikenal secara tradisional sebagai babad, wawacan, sejarah, riwayat dan hikayat (terdapat di lingkungan budaya Melayu) sedangkan Lontara khusus di Bugis-Makassar (Montana, 1994/1995, 1996).

Babad sebagai historiografi, pada umumnya kurang mengungkapkan hal-hal yang bersifat faktual, dari pada yang bersifat legendaris. Oleh karena itu, sebagai sumber penelitian sejarah, babad kurang akurat. Kondisi ini dapat dipahami, karena babad merupakan suatu kronik, yaitu catatan tentang kejadian historis tanpa adanya interpretasi terhadap fakta. Dalam penulisan kronik, seringkali menggunakan tradisi dan legenda tanpa memandang keotentikannya dan jarang disebutkan sumber informasi. Penulis kronik tidak selektif memilih kejadian, sehingga hal-hal yang faktual dan yang 'aneh-aneh' dilaporkan dalam rincian yang seimbang (Montana, 1994/1995: 13).

Babad ditulis dengan tujuan ganda. Satu sisi, babad merupakan karya sastra yang mengungkapkan kejadian-kejadian yang dialami oleh penulisnya, atau merupakan adaptasi dari cerita yang sudah turun-temurun. Pada sisi lain, penulisan babad merupakan upaya untuk mengagungkan dan memperkukuh kedudukan tokoh (raja, wali, pendeta dan panglima tentara) dalam babad tersebut (Montana, 1994/1995: 13).

Dari pemaparan di atas menunjukkan bahwa babad sebagai sebuah sumber dan bukti sejarah memiliki banyak kelemahan, dan karenanya tingkat kebenarannya juga masih diragukan. Namun, di sisi lain babad juga diakui sebagai salah satu sumber penulisan sejarah jika memang tidak ada bukti tertulis lain untuk mewakili suatu "peristiwa" kelampauan, sebagaimana dapat dilihat dari karya-karya Th. Raffles dan H.J. de Graaf mengenai sejarah Jawa dan karya Hoesein Djajadiningrat mengenai sejarah Banten, semuanya didasarkan atas babad.

Reinterpretasi terhadap data arkeologis yang dikemukakan oleh Montana (1996) di atas, bahwa data historiografi lokal yang di kemukakan (Babad Banten dan Babad Pasir) secara eksplisit memang menunjukkan adanya unsur 'benturan fisik' dalam melakukan sosialisasi Islam. Namun, perlu dipertimbangkan adanya unsur 'politis'di 
sini, ada kemungkinan yang menjadi tujuan utamanya adalah ekspansi/perluasan wilayah kekuasaan. Hal ini terefleksikan dari kutipan Babad Pasir, pupuh asmaradana
"...Beta mendengar khabar
bahwa kerajaan di barat (yang) sekarang
bernama Negara Pasir Luhur,
dewasa ini masih memeluk agama Budo.
Dan negara itu selama ini
hanya medang kori (?)
belum kita taklukkan ...."

Dan dalam babad Banten, pada halaman 27, pupuh 9- 13:

9. berkatalah Susuhunan Mahdum Jati, : "Syukur Ki Mas membagi-bagikan gonimah (harta rampasan perang).

10. Ini terjadi jika orang-orang tinggal di batas negeri (milik) ki Mas Tua (Pangeran Pasarean di Cerbon) menjadi

11. milik Ki Mas Tua, (dan) kalau orang-orang itu berdiam di batas negeri (milik) Ki Mas

12. Anom (maka barang gonimah itu) menjadi milik Ki Mas Anom, sampai (pada) akhirnya aku diberi batas, Karawang ke timur

13. (adalah) milik Ki Mas Tua (sedangkan Kerawang) ke barat menjadi milik Ki Mas Anom".

Pada kalimat "belum kita taklukan" dalam Babad Pasir mengandung maksud adanya perluasan wilayah kekuasaan oleh kasultanan Demak atas wilayah Pasir Luhur yang diperintah oleh Adipati Banyak Belanak, serta kutipan dari Babad Banten yang menyebutkan adanya pembagian wilayah Kerawang oleh Susuhunan Mahdum Jati kepada dua puteranya, yaitu wilayah Kerawang ke barat milik Ki Mas Anom dan dari Kerawang ke timur milik Ki Mas Tua, bahwa pembagian ini dilakukan setelah kerajaan Pakuan Pajajaran berhasil ditaklukkan. Hal ini menunjukkan akan tujuan sebenarnya berupa ekspansi wilayah. Jika demikian, tentu saja pengerahan kekuatan dibelakangnya menjadi suatu kebutuhan sebagai benteng pertahanan apabila terjadi perlawanan dari pihak yang diserang. Di samping itu, jika ada anggapan bahwa Islam disebarkan dengan kekerasan, tentunya terjadi kontroversi dengan ajaran yang disampaikan, sebagaimana ditegaskan dalam AI Qur'an Surat AI Baqoroh : 256, "tak ada paksaan dalam agama, sesungguhnya sudah nyata petunjuk dari pada kesesatan..." (Junus, 1984: 39).

Jadi, sebagaimana yang termuat di dalam babad bisa jadi memang ada kontak senjata, namun hal ini bukanlah semata-mata untuk tujuan pengislaman. Tujuan utama adalah 
masalah politis (ekspansi wilayah kekuasaan) dan pengislaman yang terjadi merupakan dampak dari keberhasilan penaklukan suatu wilayah. Selain itu, sebagaimana telah disinggung di atas, bahwa dalam tujuannya, penulisan babad berupaya untuk mengagungkan dan memperkukuh kedudukan tokoh dalam babad tersebut, sehingga muatan 'ekspansi' dieliminasi sebagai misi pengislaman yang memiliki bobot moral yang lebih tinggi, agar wibawa penguasa tetap terpelihara.

Lain halnya yang terjadi dengan cara-cara yang digunakan oleh para mubalig yang khusus bertujuan untuk mendakwahkan ajaran agama Islam, yang biasa dikenal dengan sebutan "wali". Mereka menggunakan cara-cara yang tidak menyimpang dari ajaran dan syariat Islam, antara lain dengan jalan perkawinan, tasawuf, pondok pesantren dan kesenian (Tjandrasasmita, 1984: 190-194). Asumsi ini diperkuat dengan fakta empiris yang dijumpai dalam wujud asimilasi tinggalan arkeologi yang berada di sepanjang pesisir utara Jawa yang merefleksikan tindakan penyebaran Islam dilakukan dengan jalan damai dan persuasif.

Sejalan dengan pendapat Montana (1996), data fisik menunjukkan adanya akulturasi, yaitu proses pengintegrasian nilai asing ke dalam kebudayaan lokal tradisional. Penekanannya pada sifat integrasi, dan bukan pemaksaan, yaitu berupa penjiwaan dan reintegrasi struktur budaya lama berkat pinjaman budaya dari luar. Tuntutan asimilasi pun merupakan seluruh problematika akulturasi (Bakker, 1984: 115). Dalam akulturasi, dari dua pihak yang berbeda diciptakan suasana koeksistensi. Kedua belah pihak saling menghormati, saling pengertian bahkan bekerjasama dalam kepentingan yang terbatas dan menutup diri dari nilai pihak lain. Mereka berdialog dan tidak berpindah dalam struktur budaya yang dihadapinya. Sementara itu, kemandirian kedua pihak dihapus, luluh dalam keadaan baru (Bakker, $1984: 121$ ).

Bentukan dari proses ini dapat dicontohkan pada perwujudan ragam-ragam hias yang ada di Masjid Agung Demak. Secara fisik, ragam hias tersebut merupakan cerminan budaya pra-Islam, namun kemudian dimodifikasi sedimikian rupa sehingga dimaknai sebagai lambang-lambang tasawuf (Saptono, 1994/1995: 32-39). Tasawuf sendiri merupakan salah satu strategi yang efektif dalam sosialisasi Islam di Indonesia (Masyhudi, 2001: 68-78), hal ini terbukti dengan banyaknya karya-karya sastra tradisional yang bermuatan mistis-religius yang diwarnai ajaran-ajaran tasawuf. Selain itu, contoh-contoh tinggalan yang telah dipaparkan di bagian atas tulisan ini merupakan cerminan bagaimana proses akulturasi terjadi. 
Menyinggung pendapat adanya dua cara penyebaran Islam, baik secara perseorangan maupun secara politis, mengandung pengertian bahwa perseorangan yang dimaksud adalah, murni karena niatan yang ada dari dalam hati untuk mengkhususkan diri mendakwahkan Islam tanpa ada tendensi di dalamnya selain kewajiban bagi setiap muslim untuk berdakwah, hal ini tercermin dalam hadist nabi Muhammad SAW: “... sampaikanlah dakwah walau satu ayat". Kecenderungannya, penyebaran yang dilakukan dengan cara persuasif, karena setidaknya mereka telah memahami sepenuhnya tentang ajaran dan syariah agama Islam serta hakekat dakwah itu sendiri.

Di lain pihak, anggapan yang menyebutkan secara politis, bisa jadi merupakan dampak dari maksud yang sebenarnya, karena mereka memiliki tujuan yang tidak semata-mata untuk sosialisasi Islam, tapi lebih menitikberatkan pada segi 'politis' dan ini berkaitan dengan 'ego' seorang penguasa untuk menunjukkan kekuasaannya, bahwa apa yang dikatakan seorang penguasa itulah yang akan terjadi, "sabdo pandhito ratu". Jadi, saat wilayah yang baru saja diserang dapat ditaklukan, maka saat itu pula wewenang dari penguasa baru untuk menentukan segalanya termasuk keyakinan yang harus dianut oleh seluruh rakyat pun berlaku.

\section{$\mathbf{P}$}

\section{enutup}

Akhirnya, sebagaimana yang telah dikatakan di awal uraian bahwa simpulan yang dihasilkan bukanlah merupakan suatu yang bersifat 'justifikasi' karena kembali pada pandangan post-modernisme bahwa "makna" suatu data arkeologi bergantung pada interpretasi dari si penafsir untuk menafsirkannya. Celah ini memungkinkan untuk menampung pandangan-pandangan lain dari berbagai versi, sehingga tidak ada interpretasi tunggal.

Demikian juga halnya dengan interpretasi terhadap cara sosialisasi Islam yang dilakukan di Jawa, bisa dikatakan secara radikal dan bisa juga secara persuasif tergantung dari sudut pandang bagaimana dia dipandang, tujuan serta niatan si pemandang itu sendiri yang juga berpengaruh akan "makna" yang ditimbulkan. 


\section{KEPUSTAKAAN}

Abdullah, Taufik (ed). 1985. Sejarah Lokal di Indonesia. Yogyakarta: Gadjah Mada University Press.

Bakker, J.W.M. 1984. Filsafat Kebudayaan Sebuah Pengantar, Yogyakarta: penerbit yayasan Kanisius

Graaf, H.J. de, dan Th. G. Pigeaud.1985.Kerajaan-Kerajaan IsIam Pertama di Jawa. Kajian Sejarah Politik Abad ke-15 dan ke-I6. Jakarta: Penerbit PT. Grafiti Press.

Iqbal, Muhammad Zafar. 1995. "Kedatangan dan Perkembangan Islam di Indonesia" dalam Buletin Al-Turas, Vol.I. No. 2, IAIN Syarif hidayatullah, Jakarta, HIm. 10-16.

Junus, Mahmud. 1984 Tarjamah Al-Quran Al-Karim, Jakarta : PT Al-Maarif.

Masyhudi nfn. (2001). Peranan Tasawwuf.Dalam Sosialisasi Islam Di Indonesia. Berkala Arkeologi 2l(1) 68-78. https://doi.org/10.30883/jba.v2lil.834

Montana, Suwedi. 1994/95. "Walisanga dan Wayang dari Kajian Naskah Lama", Kebudayaan No. 7, Th. IV., Jakarta: Depdikbud, Hlm. 11-19

1995. "Perbedaan dalam Cara Penyebaran Agama Islam di Jawa pada Abad ke 15-17 (Kajian atar Historiografi Lokal dan Asimilasi Tinggalan Arkeologi)", Buletin Forum Arkeologi, No. 2, Balai Arkeologi Denpasar, HIm. 12-37.

Salam, Solichin. 1960. Sekitar Wali Sanga. Kudus : Penerbit "Menara Kudus".

Saptono, Nanang. 1994/95. "Lambang-lambang Tasawuf Pada Ragam Hias

Masjid Agung Demak", Kebudayaan, No. 8, Th. IV. Jakarta :

Depdikbud. HIm. 32-39.

Tanudirjo, Daud Aris., 1995. "Kajian Budaya Bendawi Modern dan Arkeologi", Buletin Artefak 15, , HIm.12-21.

Tanudirjo D. A. (1994). Epigrafi Indonesia Dalam Kerangka Pikir Pasca - Modernisme. Berkala Arkeologi 14(2) 10-16. https://doi.org/10.30883/jba.v14i2.634

Tjandrasasmita, Uka. 1976. "Sepintas Mengenai Peninggalan Kepurbakalaan Islam di Pesisir utara Jawa", Aspek-aspek Arkeologi Indonesia, No.3., Jakarta: Proyek Pembinaan Kepurbakalaan dan Peninggalan Nasional.

1984. Sejarals Nusional Indonesia. Jakarta : PN Balai Pustaka. 